\title{
Is Open Access the future of scholarly journal publishing?
}

\author{
Bo-Christer Björk, Dr Tech
}

\begin{abstract}
Many fields of business have been profoundly changed by the emergence of the Internet, a truly disruptive innovation. The reviewing, publishing, and retrieval of peer reviewed articles have also benefitted enormously from digitalization. At the same time the fundamental business logic of scholarly publishing is still to a large extent based on selling content to subscribers, and Open Access, ${ }^{1}$ where there are no barriers for anybody with Internet access to read the full text of articles, has increased its share less rapidly than envisaged a few years back. There is, nevertheless, no question that full open accessibility increases readership and impact, and several bibliometric studies have demonstrated varying degrees of this "OA citation" advantage. ${ }^{2}$
\end{abstract}

Mainstream OA is provided today by big specialized publishers like PLOS or BMC, but increasingly the leading commercial and society publishers are also publishing some OA journals. Both of these publishing groups generate the necessary revenue by charging the authors for dissemination, rather than readers for access. The charges (usually called APCs) are typically $\$ 2,000-3,000$ but can be as high as $\$ 5,200$ for top journals like Nature Communications. Publishers have also launched a particular new type of OA journal, that peer reviews only for scientific soundness, not anticipated novelty or impact, and has a very broad scope. The two leading mega journals (PLOS ONE and Scientific Reviews) currently each publish over 20,000 articles per year. ${ }^{3}$ In addition, the vast majority of subscription journals from major publishers now offer authors the possibility to "open up" individual articles, against a sizable charge, of course. ${ }^{4}$

Corresponding author: Bo-Christer Björk, Professor of Information Systems Science

Contact Information: Bo-christer.bjork@hanken.fi

DOI: 10.12746/swrccc.v6i25.475
In fact, academics are most likely to be confronted with OA options either when their articles in traditional journals are accepted and they receive offers of such "hybrid" OA, or via the spam email that predatory OA publishers ${ }^{5}$ send out soliciting submissions in journals with non-existent peer review.

The OA movement was actually started during the 1990s by individual academics or academic institutions who founded OA journals often by converting existing ones. The launching of these journals was powered by a belief that opening up the scholarly literature to all researchers and even to lay people around the globe is fully in line with the fundamental ethos of science. Such journals also typically do not charge authors and are operated on shoestring budgets. Using free open source software like Open Journal System to manage the review process and publish the articles (as in this journal) has helped keep the costs reasonable. Even today almost two thirds of the over 10,000 journals indexed in the Directory of Open Access Journals (DOAJ) don't charge authors. ${ }^{6}$

Many such journals have ceased publishing, but there are also many who are still publishing, such as The Journal of Information Technology in Construction, which I founded together with a few colleagues in the same field from around the world in 1996. The Southwest Respiratory and Critical Care Chronicles started publishing more recently and represents a common type of OA journal published by a university/university department. This type of $O A$ journal is particularly common in Latin America where such journals have significantly increased their global impact via the regional portal Scielo, which now hosts over 1,000 OA journals. ${ }^{7}$

Running "indie" OA journals with revenue from neither subscribers nor authors is quite vulnerable. ${ }^{8}$ Many such journals have ceased publishing when the founding editor has left, and it's very important to engage a larger group in the running of the journal 
to ensure continuity and share the workload. Getting indexed in the ISI journal index, which would help a lot in attracting manuscripts, is more difficult than for the big publishers. And many journals have simply run out of manuscripts to publish. If a journal publishes only a handful manuscripts per year, potential authors are discouraged from submitting.

As noted, it has taken a long time to establish Open Access as a viable alternative to traditional publishing. But the share of articles in full OA journals has constantly risen by around $1 \%$ per annum and is now around $20 \%$ of Scopus Indexed articles ${ }^{9}$. Hybrid OA articles add another couple of percent. Biomedicine has always been in the forefront, partly because of the strong OA mandates from important funders like the NIH and the Wellcome Trust and also because of the better possibilities to fund the APC charges in OA journals, compared to, for instance, the situation in the social sciences and humanities.

Once OA reaches a tipping point of, say, one third of all articles, there will be no going back, and developments are likely to accelerate with major publishers starting to convert their existing subscription journals to $\mathrm{OA}$ in large numbers The licensing agreements currently offered by publishers like Springer to individual universities and even national consortia, which bundle subscription access to their full journal portfolio with full hybrid OA to all authors in the participating universities, offer one smooth transition path.

Keywords: Open Access, electronic journals, editorial, Internet
From: Hanken School of Economics, Helsinki, Finland Submitted: 5/16/2018

Conflicts of interest: none

This work is licensed under a Creative Commons Attribution-ShareAlike 4.0 International License

\section{REFERENCES}

1. Suber P. Open Access. MIT Press. 2012, 230p, https://mitpress. mit.edu/books/open-access

2. Wagner A. Open access citation advantage: an annotated bibliography. Issues in Science and Technology Librarianship 2010 Winter; 60: doi.10.5062/F4Q81B0W

3. Björk, B-C. Evolution of the scholarly mega-journal, 2006-2017. PeerJ 2018;6:e4357, DOI 10.7717/peerj. 4357.

4. Laakso M, Björk, B.-C. Hybrid open access-A longitudinal study. Journal of Informetrics 2016 November; 10(4): 919-932.

5. Bohannon J. Who's afraid of peer review. Science 2013; 342(6154):60-65.

6. Morrison H, Salhab J. Calvé-Genest A, Horava, T. Open access article processing charges: DOAJ Survey May 2014. Publications 2015;3:1-16.

7. Packer A. The SciELO Open Access: a gold way from the south. Canadian Journal of Higher Education 2009; 39(3):111-126, https://www.editlib.org/p/108727/

8. Björk B-C, Shen C, Laakso M. A longitudinal study of independent scholar-published open access journals, PeerJ 2016; 4: e1990.

9. Research Information Network. Monitoring the Transition to Open Access, A report for the Universities UK Open Access Co-ordination Group. 2015. https://www.acu.ac.uk/researchinformation-network/monitoring-transition-to-open-access. 